\title{
HEALTH PROMOTION IN OLDER AGE GROUPS AS AN OBJECTIVE OF THE SENIOR POLICY: EUROPEAN CHALLENGES
}

\author{
Arkadiusz Marzec \\ Akademia im. Jana Długosza w Częstochowie, Polska
}

\begin{abstract}
Successful ageing is understood to mean a satisfactory health status, high level of financial independence, firm family and social ties and opportunities for self-realization. The best form of health promotion among the elderly is to promote physical activity. Physical and recreational health-oriented activity and prevention of diseases helps improve physical endurance and strength, and increase muscle mass, flexibility and overall motor coordination. Adequate level of physical exercise at older age effectively prevents ageing processes and ensures maintaining good psychophysical fitness, thus stimulating social integration. The study presents selected forms of recreational forms of physical activity of older adults in local environments resulting from the needs of this group of people and initiatives of local selfgovernments to promote health.
\end{abstract}

Keywords: activity, senior policy, health promotion, physical recreation, older adults, sport, ageing, health.

\section{Introduction}

The number of people in the retirement age is on the increase in all the European states, with these tendencies being also noticeable in Poland. According to the WHO, the number of adults at the age of over 60 years by 2050 will reach $22 \%$ of general population and the number of people aged 80,90 or 100 will be rising (http://www.zycie.senior.pl/swiat-się-starzeje-8211-nowe-statystykiWHO2016). This phenomenon also concerns Polish society and it is expected that, compared to Europe in total, the ageing process should occur the fastest. In 2000 , the percentage of people aged $65+$ in the general number of citizens was ca. $13 \%$, whereas it is estimated that this number will have accounted for over $30 \%$ by 2050 (Henzel, 2014). The projections of the population growth presented by the Central Statistical Office of Poland (GUS) showed that the Polish population of people aged $80+$ will increase substantially (to ca. 2.57 million), with three times more people aged 100+ than today (GUS, 2008).

One of the characteristics of the ageing society is singularization and feminization of the old age, i.e. high percentage of older adults with single-person 
households and the fact that around $33 \%$ of women over 75 years of age live alone and this percentage increases gradually in older age groups (SzaturJaworska, 2012).

Health prevention and conditions of treatment of older adults seems to be worse than in other EU countries, whereas poverty continues to be a serious problem in this age group. One of the nagging problems is insufficient number of geriatricians and geriatric wards as well as other specialists in the field of care for older adults. In terms of mental health, Polish older adults differ from those living in other European countries and often complain about being sad and depressed, without pleasant life, tired and hopeless. Apart from poor health, the phenomenon of social marginalization of older and disabled people is being observed, followed by poor family, neighbourhood and social ties, e-exclusion (digital exclusion) connected with lack of access to the Internet or insufficient computer use skills (Błędowski et al., 2012).

WHO experts are warning that in the countries with low and medium incomes, older adults experience difficulties with the access to long-term care and rehabilitation, which leads to the changes in the systems of health care and adjustment to the needs of this population.

The problem of old age is of both individual and social character, which means the need for purposive and long-term initiatives of the organizations of public administration and social services and non-governmental institutions and organizations in terms of the improvement in the quality of life of older adults. Population ageing have become the economic and social problem. Therefore, the EU and its member states attempt to minimize the effects of this phenomenon and take measures to make society younger (the 500+ governmental support program was implemented in 2015 in Poland to improve vocational and social activity of older adults.

In Poland, activity of older adults in the labour market continues to be low. Therefore, the aim of the current senior policy is to start initiatives to stimulate the activity of older adults and, consequently, to enhance their psychophysical fitness, with particular focus on physical recreation, which has the most beneficial effect on their mood and health status (Założenia Długoterminowej Polityki Senioralnej w Polsce, 2014).

This problem is very topical and important from both the individual and social standpoints. Therefore, local communities implement programs to support older adults and improve the quality of living of the oldest generation of Poles (Program działań na rzecz seniorów na lata 2014 - 2020, 2014). The focus of this study is on the needs of older adults and opportunities for meeting these needs in the large urban environment of the city of Częstochowa in Poland, with particular emphasis on the initiatives to promote health and physical activity. 
The study was conducted in 2016 in a group of 210 older people who participated in the University of the Third Age (116 women and 94 men) and participants of sports and recreation classes in the area of the city by the City's Sports and Leisure Centre (Miejski Ośrodek Sportu i Rekreacji, MOSiR), including „Zumba Gold" classes. The method of the diagnostic survey and the questionnaire technique was used. The main technique was survey and the tool was provided by the questionnaire oriented towards older adults (citizens of the city). The study presented certain initiatives of local communities aimed at promotion of healthy lifestyles among the oldest age groups.

\section{Health promotion through recreation and sport of older adults}

Health promotion in all age groups represents the pillar of health policies implemented by the WHO and consists in activities aimed at improving health status and social awareness in this field. Health promotion has been implemented not only in schools but also among adults, older adults in media and social institutions and organizations. Modern societies tend to reject the stereotypes concerning the old age and present older adults as vulnerable, ill, poor, isolated and excluded from social life (Szarota, 2000). These views have been transforming while more and more seniors understand that physical activity, rational nutrition, sleeping, safe behaviours and no addictions lead to the improved health and enhanced psychophysical fitness. With respect to the activity theory, one can conclude that each human, even at older age, needs to be active and to feel needed and helpful while the lost social roles can be compensated by various forms of activity and involvement (Dzięgielewska, 2006).

According to gerontologists, activity and sense of belonging are the best solution for the problem of old age and offer opportunities for successful ageing. Contemporary people leave in the reality that requires frequent changes in the system of values, thinking and political solutions. The ability to function in the world with other people and for other people is one of the most important challenges contemporary humans have to face. Treating older adults and disabled with respect, tolerance, dignity and sympathy are the most important values of the democratic country (Marzec, 2003). Changes that occur in the process of ageing can be considered in several aspects:

- biological: natural, irreversible physicochemical and metabolic changes, leading to self-regulatory and adaptive disturbances and morphological and functional changes.

- psychological: reduced psychophysical activity due to loosing neurotransmitters, worse cortical conduction and disturbances in functioning of senses, 
- $\quad$ social: losing the autonomy, changes in social roles, the need for care, social marginalization.

Contemporary position of older people in society depends on the decisions made by public and self-government institutions, especially on the subjective factors i.e. personality, health status and family environment. Numerous publications concerning these problems help raise awareness that the social situation of older adults in Poland is difficult.

With current demographic situation in the EU, the member states have to face the challenges of planning and implementation of the policies towards active and healthy ageing. Active Ageing Index (AAI) proposed in 2012 by the European Commission is used to evaluate the potential of older adults in terms of employment, social participation, independence, health, safety and conditions of active ageing. This index for Poland is 27.3 , with 100 representing the perfect situation i.e. $100 \%$ of task achievement. In the general ranking of the EU countries, Poland is on the 27th (last) place (the index concerns people over 55 years of age).

The concept of active ageing assumes that the person can be socially productive as long as possible i.e. produce the goods and services regardless of whether they are paid or not, including home and family activity, care for grandchildren, voluntary work and help for the neighbours (Szukalski, 2012).

The prerequisite for good functioning of a person is to meet his or her needs. Older people also have their individual needs and right to satisfy them. Regardless of the age, people feel the need for being accepted, respected and loved. The needs older adults have include participation in socially useful activities, feeling of association to a social group, performing specific roles, maintaining interpersonal contacts, the use of leisure time in a satisfactory manner, maintaining adequate mental and psychical status, health protection, access to health care maintaining good relations with the family (Strzelec, 2008). ,Adequately organized sport or recreation may in many cases replace the currently popular psychotherapy, affect physical and mental health of a person and stimulate development of satisfactory relationships with the community" (Karpuszenko, 2008, 277).

The most important factor that determines good ageing is human activity i.e. participation of older adults in family, social, cultural, recreational or political life, which allows for meeting many needs.

The effect of physical activity on brain function has been examined by many American scientists, with their findings supporting the notion of neurobiological effects of physical activity (Ericksenn, Hillman et al., 2015). From the physiological standpoint, human brain is the most active during physical exercise and releases endorphins and serotonin, which are chemical compounds that reduce stress, improve mood and act as antidepressants (Kramer, Erickson et al., 2006). 
Moderate-intensity aerobic exercise such as fast walk, Nordic walking, swimming or cycling help produce proteins which have a repairing effect, help restore nervous cells in the brain, strengthen nervous connections, thus leading to the improved intellectual abilities. These exercises are recommended as a means of preventive and therapeutic treatment in the Parkinson's and Alzheimer's diseases (Morgan, Gallacher et al., 2012).

A particularly recommended form of physical activity for older adults is Nordic walking, which consists in walking with special poles. The sport dates back to the twenties of the 20th century in Finland and was initially used among cross-country skiers. In Poland, the sport has grown in popularity in the last decade. It can be practised by each person regardless of the age and in different weather conditions. The specific movement technique helps improve strength and endurance of arms, reduces pressure on lower leg, hips and back, which is recommended to people with weak joints and muscles. Compared to the normal gait, this method is a good fat-burning workout whereas poles help maintain better posture, stability and balance during walking outdoors (Kostka, 2015).

Physical activity in water is very beneficial to older people since exercises in the swimming pool engage the most of muscles while preventing from overload. Aqua aerobics and physical exercise in water performed to the rhythm of the music is an attractive method of relaxing and offers many health benefits.

Water aerobics has a healing effect on the cardiovascular system, whereas the whirling motion massages the tissues thus removing toxins from the body and accelerating fat burning and helping people relax. One of very popular forms of physical recreation is dancing, whereas medicine uses this form of movement as a therapy (choreotherapy). Dancing has a positive effect on the motor, cardiovascular, digestive system, metabolism and the nervous system. It improves oxygen transport, blood circulation, flexibility of joints, pulmonary function and motor coordination. It also acts as an effective antidepressant that helps cope with stress while releasing positive emotions, motivating and helping start interpersonal contacts. The interest in zumba, which is the dance fitness program, has been rising in recent years. Simple dancing steps, various movement combinations and rhythmic music create the atmosphere of playing and relax.

In conclusion, physical activity in older adults should stimulate three basic areas of health: improve aerobic capacity, improve muscle strength, flexibility, balance and motor coordination.

\section{Selected forms of recreational activity in local communities}

In 2004, the year of Poland's accession to the EU, over $80 \%$ of older adults positively responded to this fact, since they wanted better life for their children and grandchildren while they did not expect anything from the EU. However, 
several years later, they found that EU's programs support both professionally active people and those retired. These programs are aimed to improve the quality of life, reduce morbidity through promotion of prevention of diseases and ensuring medical care. The UE promotes active ageing through preventing isolation and implementation of the projects of intergenerational integration. Polish citizens utilize programs for seniors more and more frequently and are often the members of the European Seniors' Union (ESU). The organization is dedicated to defending rights to living in dignity, improvement of social security and various facilitation for this age group.

(Grabowska, 2009).

The EU's Covenant on Demographic Change signed in January 2016 is aimed at creation of the local community to support active ageing through exchange of best practices across Europe. (Projekt AFE - INNOVNET) (www.senior.pl/tematy/unia+europejska, 2016).

The Ministry of Family, Labour and Social Policy intends to introduce, in 2017, changes in the Senior Wigor program (which will be renamed Senior+), concerning the implementation of a new forms of centres for older adults and funding of e.g. Senior+ day care centres, with professionally inactive people living in these centres for 8 hours a day from Monday to Friday and spending time actively under supervision of qualified employees ( 1 employee per 15 seniors). (www.opieka.senior.pl/84,0Senior-zastapi-Senior-Wigor,2530.html, 2016)

Table 1 The needs of seniors surveyed

\begin{tabular}{|c|l|c|c|c|c|c|c|}
\hline \multirow{2}{*}{$\begin{array}{c}\text { Ques- } \\
\text { tion }\end{array}$} & \multicolumn{1}{|c|}{ Types of needs } & \multicolumn{2}{c|}{ Women } & \multicolumn{2}{c|}{ Men } & \multicolumn{2}{c|}{ Together } \\
\cline { 3 - 8 } & & $\boldsymbol{N}$ & $\boldsymbol{\%}$ & $\boldsymbol{N}$ & $\boldsymbol{\%}$ & $\boldsymbol{N}$ & $\%$ \\
\hline 1 & Maintain good health status & 91 & 43 & 92 & 44 & 183 & 87 \\
\hline 2 & Improve financial situation & 84 & 40 & 95 & 45 & 179 & 85 \\
\hline 3 & $\begin{array}{l}\text { Maintain fitness and independence in } \\
\text { everyday life }\end{array}$ & 80 & 38 & 97 & 46 & 177 & 84 \\
\hline 4 & Better and faster access to doctors & 78 & 37 & 81 & 38 & 159 & 75 \\
\hline 5 & More frequent contacts with friends & 79 & 38 & 68 & 32 & 147 & 70 \\
\hline 6 & Not to be lonely & 56 & 27 & 69 & 33 & 125 & 59 \\
\hline 7 & Learn and extend knowledge & 58 & 28 & 41 & 20 & 99 & 48 \\
\hline 8 & Improve living conditions & 50 & 24 & 48 & 23 & 98 & 47 \\
\hline 9 & Be needed and helpful & 84 & 40 & 13 & 6 & 97 & 46 \\
\hline 10 & $\begin{array}{l}\text { Participate in cultural and } \\
\text { recreational events }\end{array}$ & 49 & 23 & 44 & 21 & 93 & 44 \\
\hline 11 & $\begin{array}{l}\text { Improve relations with the family } \\
\text { (children and grandchildren) }\end{array}$ & 34 & 16 & 39 & 19 & 76 & 35 \\
\hline 12 & Go to a sanatorium & 21 & 10 & 16 & 8 & 37 & 18 \\
\hline 13 & Go to a trip & 7 & 3 & 10 & 5 & 17 & 8 \\
\hline 14 & Work professionally & 4 & 2 & 10 & 5 & 14 & 7 \\
\hline
\end{tabular}


Apart from many threats, demographic changes which affect EU changes stimulate the development of new sectors and services. The need arises for the development of a vast array of new technologies that would help older people maintain independence and live longer in their own houses (adaptation of flats to the needs of people with reduced physical abilities, changes in the local infrastructure, technical facilities and transportation adjusted to the disabled).

Analysis of the needs of older adults should be based on their opinions. The answers to the question of "What is the most important to you now?" (multiple choice options).

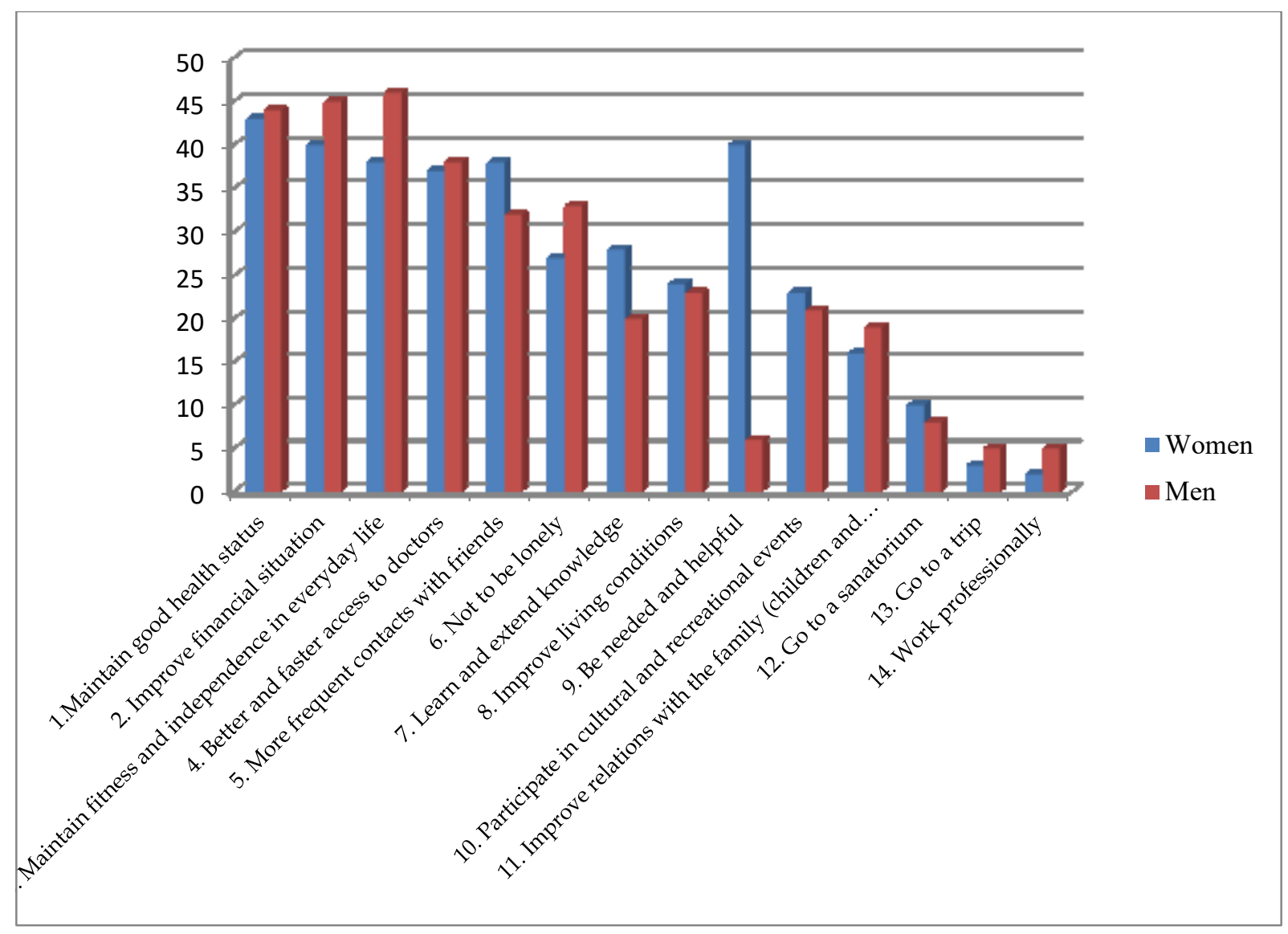

Figure 1 The needs of seniors surveyed

With regards to the question of "Which forms of activity are the most attractive to you?", the answers were: (multiple choice options). 
Arkadiusz Marzec. Health Promotion in Older Age Groups as an Objective of the Senior Policy: European Challenges

Table 2 Forms of activity

\begin{tabular}{|c|l|c|c|c|c|c|c|}
\hline \multirow{2}{*}{$\begin{array}{c}\text { Ques- } \\
\text { tion }\end{array}$} & \multicolumn{1}{|c|}{ Forms of activity } & \multicolumn{2}{c|}{ Women } & \multicolumn{2}{c|}{ Men } & \multicolumn{2}{c|}{ Together } \\
\cline { 3 - 8 } & & $\boldsymbol{N}$ & $\boldsymbol{\%}$ & $\boldsymbol{N}$ & $\boldsymbol{\%}$ & $\boldsymbol{N}$ & $\boldsymbol{\%}$ \\
\hline 1 & Socializing & 102 & 49 & 81 & 38 & 183 & 87 \\
\hline 2 & $\begin{array}{l}\text { Participation in the University of the } \\
\text { Third Age program }\end{array}$ & 107 & 51 & 58 & 28 & 165 & 79 \\
\hline 3 & "Zumba Gold" dance fitness classes & 109 & 52 & 13 & 6 & 122 & 58 \\
\hline 4 & Group trips in Poland and abroad & 84 & 40 & 31 & 15 & 115 & 55 \\
\hline 5 & Going to cinemas and theatres & 88 & 42 & 21 & 10 & 109 & 52 \\
\hline 6 & Watching the TV and DVD videos & 25 & 12 & 81 & 39 & 106 & 51 \\
\hline 7 & $\begin{array}{l}\text { Going with grandchildren to the } \\
\text { playground }\end{array}$ & 46 & 22 & 54 & 26 & 100 & 48 \\
\hline 8 & Dancing and games & 81 & 39 & 6 & 3 & 87 & 42 \\
\hline 9 & Baking, cooking & 63 & 30 & 14 & 7 & 77 & 37 \\
\hline 10 & Walking the dog & 29 & 14 & 16 & 8 & 45 & 22 \\
\hline 11 & General fitness gymnastics & 4 & 2 & 14 & 7 & 18 & 9 \\
\hline 12 & Using the Internet & 14 & 7 & 3 & 1 & 17 & 8 \\
\hline 13 & Voluntary work & 8 & 4 & 8 & 4 & 16 & 7 \\
\hline 14 & Going for a walk, Nordic walking & & & & & & \\
\hline
\end{tabular}

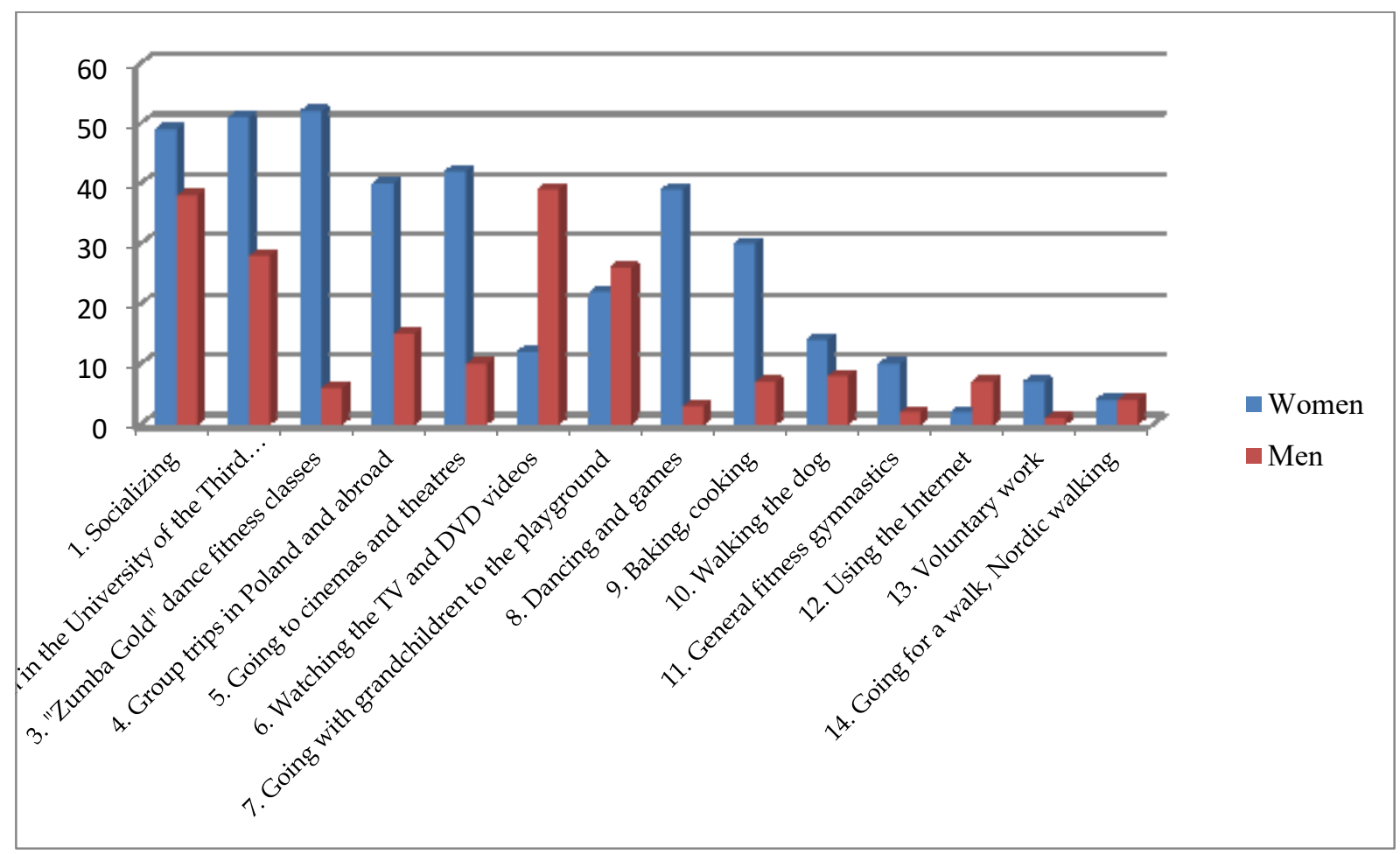

Figure 2 Forms of activity 


\section{Conclusion}

- to the most seniors, the most important thing is to maintain good health status, improve financial status and continue to be independent in everyday life,

- $\quad 3 / 4$ people wanted a faster access to medical services and more frequent contacts with friends

- almost half of the respondents want to extend their knowledge and are willing to help other people. Women want to be needed more frequently than men

- older adults need to be involved in cultural, recreational and tourist activity

- $\quad$ several seniors would like to work professionally

- the most attractive social meetings for seniors are organized in nursing homes ("Senior Homes"), the University of the Third Age, dancing classes and trips in Poland and abroad.

- half of seniors like participating in cultural events (theatre, cinema), watch $\mathrm{TV}$, walk with grandparents for a walk and cook

- the fewest people are interested in Nordic walking, using the Internet or charity and voluntary work to help others.

- there are numerous services and classes for older adults in the city.

- Activation Centre, social assistance centres, Town Hall, Municipal Sports and Recreation Centre, cultural centres, non-governmental organizations, hiking, cycling, bus excursions, sight-seeing walks, recreational trips, workouts, orienteering exercises, aerobics, zumba and salsa classes, floor dancing. There are more and more recreation playgrounds dedicated to older citizens.

- an attractive form of physical recreation is swimming and aqua aerobics classes which are organized in indoor swimming pools. The campaign "Pogodna jesień - starzej się zdrowiej" ("Happy autumn: age healthier") includes sports and recreation classes for seniors, such as gymnastics, zumba, aerobics, dancing clinics. The Częstochowa Seniorom program ("Częstochowa for Seniors") for 2014-2020 was comprised of lectures of health prevention e.g. "Adaptation of human body to physical exercise", "Human nutrition", "Obesity and its complications", Yoga and its effect on human body".

- Open Nordic Walking Częstochowa Championships have been organized since 2015, with judges assessing walking technique and race time, whereas walking sections are adequately adjusted to the age groups and abilities of participants. 
- $\quad$ The Senior Activity Centre offers a cycle of garden parties, trips for picking up mushrooms, celebration balls, physical exercise classes in the places of recreation and sightseeing excursions.

- $\quad$ "Zumba Gold" classes are organized in a sports hall and are gaining much popularity not only among women as a number of men also participate in these activities.

- „Sports Seniorympics”, „Regional Senior Olympic Games” are only a few of many sports and recreation events in the city region designed for the oldest citizens.

\section{Summary}

Seniors represent the group of people with huge intellectual and social potential that can be utilized in many domains. Contemporary seniors are aware that health and life success largely depend on psychophysical disposition and lifestyles. Many cities are engaged in the initiatives aimed at older adults, focusing on the development of local programs of activation and support for this age group of citizens. These programs are characterized by a wide scope of activities in terms of health protection and social care, including prevention.

These problems are critical from the standpoint of society and individual needs of older adults and result from the rules used in the democratic state, where weaker groups have to be particularly protected.

\section{References}

Błędowski, P. i inni (2012). Raport na temat sytuacji osób starszych w Polsce. Warszawa: IPiSS.

Dzięgielewska, M. (2006). Aktywność społeczna i edukacyjna w fazie starości. W: SzaturJaworska, B. (red.) Podstawy gerontologii społecznej (s. 160). Warszawa: UW.

Erickson, K. L., Hillman, C. H. wsp. (2015). Aktywność fizyczna mózgu i poznanie, Current Opinion In Behavioreal Sciences, 4, 27-32.

Grabowska, G. (2009). Seniorzy w UE, www.zycie.senior.pl/1470,Seniorzy-w-UniiEuropejskiej,5406.html.

Henzel, M. (2014). Eksplozja stulatków w Polsce. Polityka, 24 czerwca. http:/www.zycie.senior.pl/swiat-sie-starzeje-8211-nowe-statystyki-WHO

Karpuszenko, E. (2008). Sport i rekreacja w profilaktyce niedostosowania społecznego młodzieży. W: Kieszkowska, A. (red.) Dylematy współczesnej profilaktyki i resocjalizacji (s. 272-282). Kielce: Wyd. Uniwersytetu Humanistyczno-Przyrodniczego.

Kostka, J. (2015). Rola aktywności ruchowej w promocji zdrowia u osób starszych. http://zdrowie.ruch.pl/sece/serce.html.

Kramer, A. F., Erickson, K. L., wsp. (2006). Ćwiczenia, poznanie, a starzenie się mózgu. Journal of Appled Physiology, 101 (4), 1237/42. 
Marzec, D. (2003). Prawa człowieka - podmiotowość - tolerancja jako najwyższe wartości. W: Siedlaczek-Szwed, A. (red.) Wybrane zagadnienia pedagogiki specjalnej (s. 60-62). Częstochowa: AJD.

Morgan, G. S., Gallacher, J., Bayer, A., Fisch, M., Ebrahim, S., \& Shlomo, Ben-Y (2012). Aktywność fizyczna $w$ średnim wieku $i$ demencji $w$ późniejszym życiu. Wnioski $z$ prospektywnego badania grupy mężczyzn. (https://en.wikipedia.org/wiki/ Neurobiological effects of_physical_exercise).

Prognoza ludności na lata 2008-2035. Warszawa: GUS.

Program działań na rzecz seniorów na lata 2014-2020 „Częstochowa Seniorom”. Częstochowa 2014.

Strzelec, M. (2008). Potrzeby ludzi starszych i ich zaspokojenie w Polsce w opinii studentów. W: Kowalewski, J. T., Szukalski, P. (red.) Pomyślne starzenie się w perspektywie nauk społecznych $i$ humanistycznych (s. 228). Łódź: Wyd. UŁ.

Szukalski, P. (2012). Aktywność zawodowa. W: Błędowski, P., Mossakowski, M., Więcek, A. (red.) Aspekty medyczne, psychologiczne, socjologiczne i ekonomiczne starzenia się ludzi $w$ Polsce (s. 15 i dalsze). Poznań: TerMedia.

Szarota, Z. (2000). Formy aktywności mieszkańców domów pomocy społecznej dla osób starszych. W: Panek, A., Szarota, Z. (red.) Zrozumieć starość (s. 50). Kraków: Wyd. AP.

Szatur-Jaworska, B. (2012). Sytuacja rodzin i więzi rodzinne ludzi starszych i osób na przedpolu starości. W: Błędowski, P., Mossakowski, M., Więcek, A. (red.) Aspekty medyczne, psychologiczne, socjologiczne i ekonomiczne starzenia się ludzi $w$ Polsce (s. 422). Poznań: TerMedia.

www.opieka.senior.pl/84,0Senior-zastapi-Senior-Wigor,2530.html 2016.

www.senior.pl/tematy/unia+europejska 2016.

Założenia Dtugoterminowej Polityki Senioralnej w Polsce na lata 2014 - 2020. Monitor Polski, 4 luty 2014, poz. 118. 